\title{
XIV-XV. YÜZYILLARA AİT OSMANLI CAMILERINNDE GÖRÜLEN TUĞLA-TAŞ ALMAŞIKLIĞI ÜZERİNE GÖZLEMLER
}

\author{
Mehmet KUTLU*
}

\section{$\underline{\text { Özet }}$}

$\mathrm{Bu}$ çalışma, XIV-XV. yüzyıllara ait Osmanlı camilerinde görülen tuğla-taş almaşık duvarları incelemektedir. Almaşık duvar örgüsünün farklı uygulamaları ve bunlarla yakından ilişkili olan derz, kemer, kasnak ve saçak özellikleri de ele alınmıştır. Yapılan değerlendirmede iki yüz yıllık zaman dilimi içinde meydana gelen değişim ve gelişimin analizi ve yorumlanması, tarihî süreç bağlamında yapılmıştır. Almaşık duvar uygulamalarının kökeni ve Bizans yapılarıyla ilişkisi üzerinde durularak Osmanlı camilerinde görülen almaşık duvarın, Bizans örnekleriyle benzer ve farklı yönleri tartışılarak karakteristik özellikleri ortaya koyulmaya çalışılmıştır. Konuya eğilen diğer önemli çalışmalara değinilmiş ve ortaya çıkan sonuçlar karşılaştırılarak yorumlanmaya çalışılmıştır. Daha önceki yapılan bazı çalışmalara göre XIV. yüzyılda görülmediği ve XV. yüzyılda birden bire ortaya çıktığ1 belirtilen 2/1 düzende dikey tuğla-taş almaşıklığının, aslında XIV. yüzyıla ait dört yapıda bulunduğu anlaşılmıştır. Yine XV. yüzyıla ait yapılarda görülmediği belirtilen 4/1 dikey tuğla-taş almaşıklığın üç yapıda bulunduğu görülmüştür.

Daha önceki bazı çalışmalarda XV. yüzyıla ait sadece iki yapıda kesme taş-tuğla almaşıklığı görüldüğü tespit edilirken, bu çalışmanın sonucunda XV. yüzyıla ait on dokuz yapıda kesme taş-tuğla almaşıklığı tespit edilmiştir. Diğer bir deyişle, kesme taş malzeme kullanımı XVI. yüzyılda birden bire patlama yaparak ortaya çıkmamış, XV. yüzyılda belirli bir artış süreci takip etmiştir.

Anahtar Kelimeler: Erken Dönem Osmanlı Camileri, almaşık duvar, tuğla-taş almaşık duvar, almaşıklık duvar tipleri

206

\section{OBSERVATIONS ON THE ALTERNATING BRICK AND STONE WALLS OF OTTOMAN MOSQUES FROM THE $14^{\text {th }} \& 15^{\text {th }}$ CENTURIES}

\section{$\underline{\text { Abstract }}$}

This article examines the alternating brick and stone walls of Ottoman mosques from the $14^{\text {th }}$ and $15^{\text {th }}$ centuries. Different types of the alternating walls and closely related architectural features such as arches, friezes, drums for domes, and mortar beds are also investigated. The change and improvements in the alternating walls of Ottoman mosques for two centuries are analyzed, evaluated and interpreted. Besides that the origin of the alternating wall and the differences and similarities between Ottoman and Byzantine examples of alternating walls are discussed in order to reveal the features of the Ottoman

* Arş. Gör., Ege Üniversitesi Edebiyat Fakültesi Sanat Tarihi Bölümü, İzmir, Türkiye.

E-mail: tutluca1105@ hotmail.com. 
alternating walls. Furthermore, the previous studies in this topic are explained and the results of this article are compared with those studies. It is been uncovered that the $2 / 1$ system of perpendicular alternating brick and stone walls is evident in four of the $14^{\text {th }}$ century Ottoman mosques, despite some of the earlier studies claiming that the system didn't exist in the $14^{\text {th }}$ century and suddenly appeared in the $15^{\text {th }}$ century. It is also been claimed that the $4 / 1$ system of perpendicular alternating brick and stone walls is disappeared in the $15^{\text {th }}$ century Ottoman mosques, however this study reveals it in three mosques of that period.

In addition to that the use of well-cut stone blocks and bricks on the alternating walls is recorded in nineteen of the $15^{\text {th }}$ century Ottoman mosques; despite that some of the previous studies were found it in only two of the mosques from the $15^{\text {th }}$ century. Thus the use of well-cut stone blocks had not become widespread suddenly in the $16^{\text {th }}$ century but it went through a process of increasing from the $15^{\text {th }}$ century.

Keywords: Early Ottoman Mosques, the alternating Wall, the alternatinf brick and stone wall, types of the alternating walls

A nadolu Türk mimarisi çağlar boyunca taş ve tuğlanın farklı duvar örgü tekniklerinde kullanımına tanıklık eden örneklere sahiptir. Bu durum dönemden döneme ve yöreden yöreye farklılıklar göstermektedir. Osmanlı camilerinde malzeme kullanımı bağlamında bu konu ele alındığında tuğla örgü, taş örgü ve bu çalışmanın konusu olan tuğla ve taşın belirli bir düzen dâhilinde kullanıldığ 1 almaşık örgünün tercih edildiği görülür.

Almaşık Duvar, "aşağıdan yukarıya doğru ardışık olarak sıralanan farklı malzeme dizileriyle oluşturulmuş duvar" anlamına gelmektedir. ${ }^{1}$ Ancak almaşıklık, aşağıdan yukarıya doğru olduğu gibi, yatay olarak da uygulanabilir. Afife Batur’a göre almaşıklığın başlıca iki türü vardır: Aynı malzeme almaşıklığl ve farklı malzeme almaşıklığı.

Bunlardan birincisinde, aynı tür malzemenin farklı büyüklük ve renk özelliklerine göre tekrarlanarak kullanımı söz konusudur. Aynı malzeme almaşıklı̆̆ başlıca, renk ve büyüklük almaşıklığı şeklinde görülür. Renk almaşıklığı, örneğin iki veya daha fazla farklı renkte taş blokların sıralar halinde belirli bir düzen dâhilinde tekrarlanarak duvar örgüsünde kullanımı olarak açıklanabilir. Büyüklük-küçüklük almaşıklığı ise farklı boyutlardaki taş blokların sıralar halinde belirli bir düzenle tekrarlanarak duvar örgüsünde kullanılması şeklinde açıklanabilir.

Farklı malzeme almaşıklı ̆̆ $ı$ ise, aynı duvar örgüsünde en az iki farklı malzemenin dönüşümlü olarak tekrarı ile oluşturulan almaşıklık türüdür. Bu türün en çok görüleni tuğla ve taş sıralarıyla yapılan duvar örgüsü şeklindedir. Bu çalışmanın amacı da, XIV - XV. yüzyıl Osmanlı camilerinde tuğla ve taş malzemenin kullanım esaslarını incelemektir.

1 Sözen ve Tanyeli, 2003, 18.

2 Batur, 1970, 136. 
Öncelikle; tuğla-taş almaşıklığının üç farklı çeşidi olduğu görülmektedir: Dikey, yatay ve bileşik almaşıklık. Dikey Almaşıklık, tuğla ve taş malzemenin sıralar halinde aşağıdan yukarıya ardışık olarak örülmesiyle meydana gelmektedir. Esasen tuğla ve taşın dikey almaşıklığı duvarı güçlendirmek amaçlı ahşap hatıl tekniğinin uygulanmasıyla alakalıdır. Ahşap hatıl tekniğinde, taş örgü sıra veya sıraları üzerine duvar örgüsünü güçlendirmek amacıyla ahşap hatıllar kullanılmakta ve bu hatılların cepheye dönük yüzleri tuğla ile örülmektedir.

Bununla birlikte dikey almaşıklığın çok yaygın uygulama biçimleri vardır. Bunlar yalnızca bir düzen esasına göre dikey almaşıklığın uygulamasıyla ortaya çıkmıştır. Basit dikey almaşıklık olarak tanımlanan bu uygulamalarda, tuğla ve taş sıraları aynı duvar örgüsünde genellikle 1/1, 2/1,3/1 veya 4/1 düzende tekrarlanan tuğla-taş malzeme kullanılarak sıralanmaktadır. XIV - XV. yüzyıla ait Osmanlı camilerinde genellikle 3/1 ve 2/1 düzen dikey almaşık duvar örgüsü tercih edilmiştir.
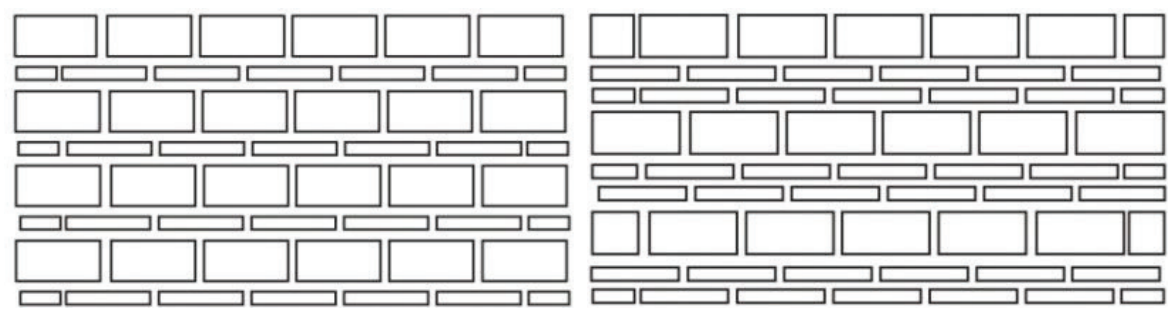

Şekil 1 ve 2: Dikey Almaşık Tuğla-Taş Duvar 1/1 ve 2/1 (basit düzen) uygulamaları.

Dikey almaşıklığın kompleks uygulanmasında ise aynı duvar örgüsündeki tuğla-taş sıraları birden fazla düzenle ardışık olarak yinelenmektedir. Örneğin; 3/1 ve 1/1 düzenlerin uygulandığ 1 kompleks uygulama, kısaca şu şekilde açıklanabilir: Önce üç tuğla sırasını bir taş sırası ve daha sonra bir tuğla sırasını bir taş sırası takip eder ve bu şekilde tekrarlanarak tüm duvar örgüsü oluşur. Bu uygulamada iki ayrı düzen bir arada kullanılmıştır.
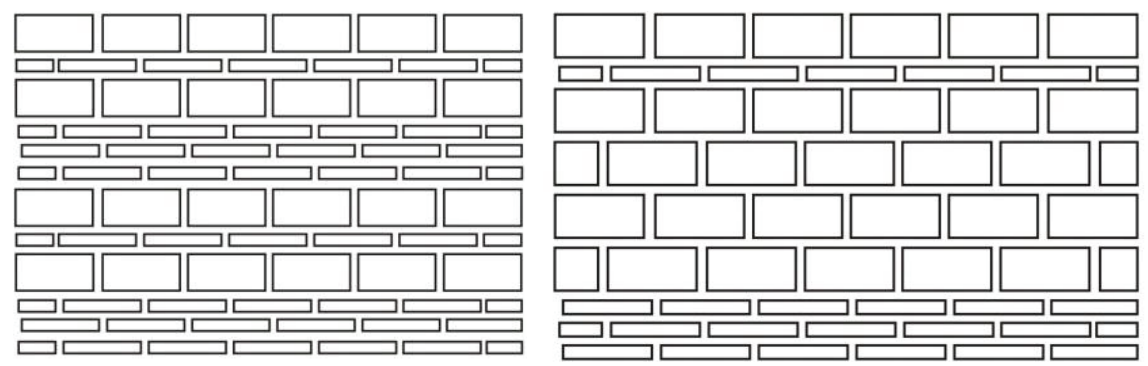

Şekil 3 ve 4: Dikey Almaşık Duvar 3/1+ 1/1 ve 3/4 +1/1 (Kompleks düzen). 
Yatay almaşılklk ise aynı sıra üzerinde taş ve tuğlanın yan yana örülmesiyle yatay eksende tekrarlanmasıyla uygulanmaktadır. Bu yöntemde taşların arasına bir veya iki adet dikine tuğla koyulması en yaygın uygulamadır.
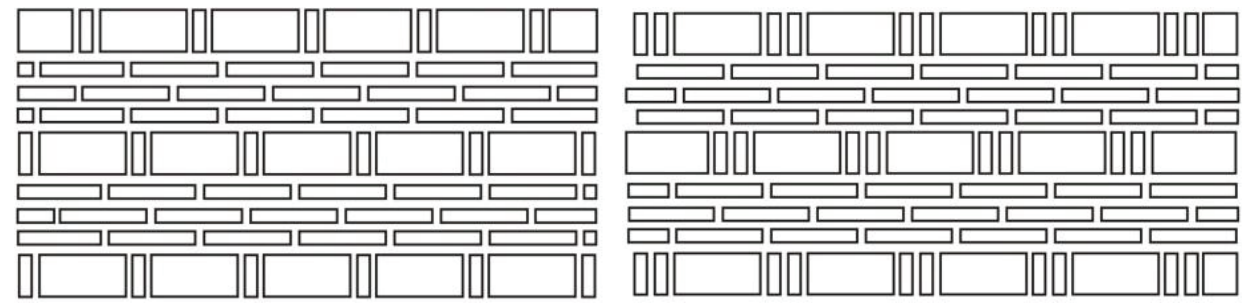

Şekil 5 ve 6: Yatay Almaşık Duvar (dikine 1 tuğla) ve (dikine 2 tuğla) uygulamaları

Bileşik almaşılklık taş ve tuğlanın hem dikey hem de yatay eksende ardışık olarak kullanılmasıyla meydana getirilen duvar örgü tekniğidir. Bu tekniğe kasetleme tekniği de denilmektedir.

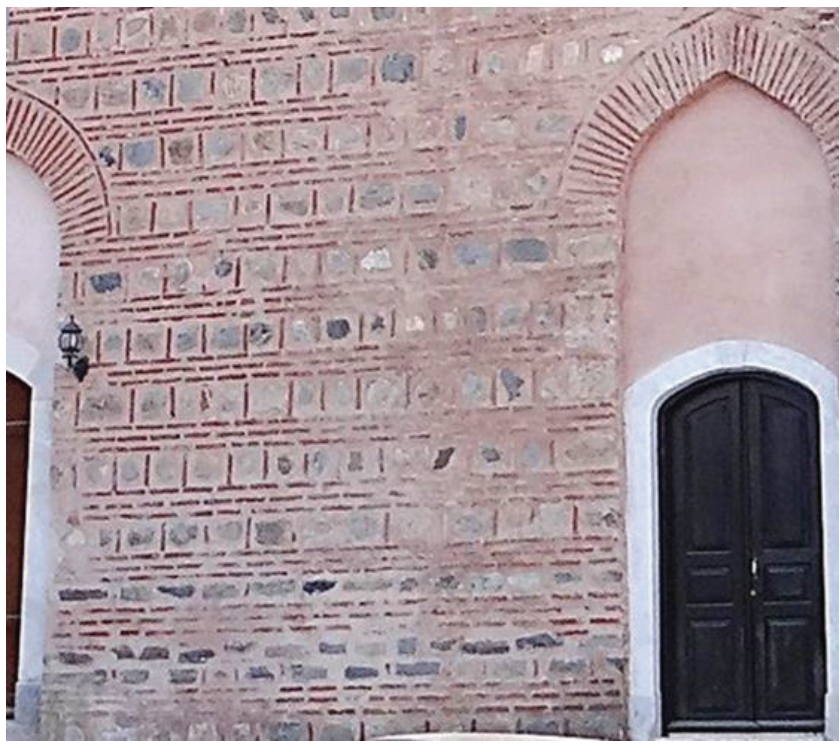

Fotoğraf 1: Bursa

Muradiye Camii duvar örgüsünde kasetleme tekniği. (Fot. M. Kutlu)

Bugüne kadar almaşık duvar örgüsü üzerine bazı çalışmalar yapılmıştır. Bu çalışmalardan ilk akla geleni ve büyük çığır açanı Afife Batur'un 1970 yılında yayımlamış olduğu Osmanlı Camilerinde Almaşık Duvar Üzerine ${ }^{3}$ adlı makalesidir. Makale, duvar

3 Batur, 1970,135-216. 
ve yapı malzemelerini "sistem yaklaşımı" çerçevesinde temel birimler, alt birimler ve bunların birbirleriyle ilişkileri bağlamında açıklamayı amaçlamıştır.

Söz konusu çalışmada önce almaşık duvarın tanıtımı yapılmış, kısaca kökene dair öneriler aktarıldıktan sonra XIV - XVIII yüzyıllar arasına tarihlenen ve almaşık duvar örgüsü bulunan Osmanlı camileri kronolojik bir sira ile incelenmiştir. En yaygın görülen almaşıklık olan tuğla-taş almaşıklğg ağırlıklı olarak incelenmekle birlikte, büyüklük ve renk almaşıklıkları da az sayıdaki yapı örnekleri bağlamında ele alınmıştır. Tuğla-taş almaşıklığı yönünden incelenen yapılarla ilgili bilgiler bir tabloda toplanarak değerlendirilmiştir. Tabloda uygulanan almaşıklık düzenleri, derz özellikleri, saçak, kasnak, kemer ve minarede görülen özellikler ile birlikte bezeme amaçlı uygulama ve teknikler de kapsama dâhil edilerek analiz edilmiştir. Buradan hareketle yüzylllara göre bazı genellemelere ulaşılmıştır. Görsel açıdan yer yer almaşıklı düzenlerini gösteren şekiller ile birlikte metnin sonunda incelenen yapılara ait resimler de verilmiştir.

Konuyla ilgili diğer bir çalışma, M. İ. Tunay tarafından 1976 yılında VIII. Türk Tarih Kongresi'nde bildiri olarak sunulan ve 1983 yılında yayınlanan "Geç Bizans Erken Osmanlı Duvar Teknikleri başlıklı makaledir. Tunay, Geç Bizans ve Erken Osmanlı yapılarının duvar tekniklerinde benzerlik olup olmadığını yürek motifi kullanımı bağlamında ele almıştır. Yaptığı karşılaştırmalar sonucunda Yenişehir Seyyid Mehmed Dede Zaviyesi ile bazı Bizans yapılarında yürek motifi ortak olmasına rağmen duvar dokusundaki farklılıktan dolayı zaviyenin Türk ustalarca inşa edildiğini, ancak mimarları arasında Bizans kökenli usta veya mimarların da bulunduğunu ortaya çıkarmıştır. ${ }^{4}$

Bununla birlikte Ahmet Ersen tarafından 1986 yılında İstanbul Teknik Üniversitesi'nde doktora tezi olarak hazırlanan ve sonrasında yayınlanmış olan Erken Osmanlı Mimarisinde Cephe Biçim Düzenleri ve Bizans Etkilerinin Niteliği başlıklı çalışma da önemlidir. Geç Bizans - Erken Osmanlı olarak adlandırılan dönemin sosyal, ekonomik ve toplumsal durum ve yapısından söz edilmiş ve bunların mimari üzerine etkileri irdelenmiştir. Daha sonra Bizans yapılarında görülen almaşık duvar ve özellikleri ele alınmış ve diğer yapı elemanlarıyla ilişkileri üzerinde durulmuştur. Bizans cephe biçimlerinden sonra Erken Osmanlı mimarisinin analizine geçilmiştir. XIV. yüzyıl Osmanlı almaşık duvarı incelenirken, Bizans almaşı duvarı ile oldukça önemli karşılaştırmalara yer verilmiştir. Hangi özelliklerin ortak ve Bizans’tan kaynaklandığı, hangi açılardan bir farklılık söz konusu olduğu ve XIV. yüzyılda Osmanlı mimarisinin nasıl bir aşama kaydettiği ile ilgili değerlendirmelere yer verilmiştir.

Diğer bir çalışma, Y. Selçuk Şener tarafından 1993'te tamamlanan 14. Yüzyıl Bursa Yapılarında Erken Osmanlı Duvar Örgüsü başlıklı yüksek lisans tezidir. ${ }^{5}$ Şener, öncelikle duvar örgüsünde kullanılan malzemeleri açıkladıktan sonra katalog halinde 14. yüzyıla ait Bursa yapılarını tek tek ele almışıtır. Yapıları kronolojik sıraya göre ele almış,

4 Tunay, 1983, 1691-1696.

5 Şener, 1993, 1-216. 
yap1 türlerine göre sınıflandırmamıştır. Her bir yapının geçirdiği onarımlarla birlikte kullanılan malzemenin (taş blok boyutları, tuğla boyutları) özellikleri ve duvar örgüsünde uygulanan düzenler ve derz özelliklerini de incelemiştir. Çalışmanın sonunda yer alan şekiller, fotoğraflar ve tablolar oldukça yararlıdır.

Bunlara ek olarak, İlknur Aktuğ Kolay’ın 1999 yılında yayınladı̆̆ı Batı Anadolu 14. Yüzyıl Beylikler Mimarisinde Yapım Teknikleri adlı kitabı da bu konudaki önemli çalışmalardan biridir. Yazar, önce Batı Anadolu'da Türkler öncesinde görülen yapı inşa geleneklerini ele almış, sonra duvar teknikleri, malzeme ve yapım tekniklerini incelemiştir. Sonraki bölümlerde Batı Anadolu Türk Beyliklerinde görülen yapı teknikleri, malzeme kullanımı, yapı elemanlarındaki uygulamaları inceledikten sonra bu özelliklerin bölgesel dağılımı ve kendisinden önceki Selçuklu ve İran mimarileri ile benzerlik ve farklılıklarına yönelik değerlendirme yapılmıştır.

Afife Batur'un adı geçen çalışması, mimaride kullanılan malzemeye daha dikkatli yaklaşılması gerektiği konusunda bir farkındalık yaratmıştır. Ancak bu çalışmadaki verilerin yeniden incelemeye alınmasında yarar vardır.

Bu nedenle giriştiğimiz çalışmada, öncelikle Afife Batur'un makalesinde esası teşkil eden Marmara bölgesi yapılarının sayısını artırmak ve bu bölge dışındaki tuğla-taş almaşıklığı görülen Osmanlı camilerine ait verilerin de toplanmasıyla daha geniş bir veri üzerinden değerlendirme yapmak amaçlanmıştır. Bu işlem yapılırken özgün özelliklerini koruyamayan yapılar listeden çıkarılmış ve inceleme kapsamına dâhil edilmemiştir. Ayrıca aynı yüzyıla ait yapıların malzeme, almaşıklık tekniği, derz, saçak ve kasnak özelliklerinde de söz konusu süreçte nasıl bir değişim, dönüşüm veya gelişim meydana geldiğine dair fikir yürütmek amaçlanmıştır. Renk ve büyüklük almaşıklığı çalışma kapsamına alınmamıştır. İncelenen yapı sayısı artırılırken, yine, tuğla-taş almaşıklığının kemer ve minarelerde görülen uygulamaları ile dekoratif amaçlı kullanımı konuları araştırma dişında tutulmuştur.

\section{Almaşık Örgünün Kaynağı}

Anadolu Türk mimarisinde XIV. yüzyıldan itibaren görülmeye başlayan tuğlataş almaşıklığı, yaygın kanaate göre kaynağını, yüzyıllardır aynı tekniği kullanan Bizans mimarisinden almaktadır. Bizans yapılarında görülen tuğla-taş almaşıklığına Roma Dönemi'nde uygulanmış olan opus listatum ve bir türü olan opus mixtum duvar örgü tekniğinin kaynaklık etmiş olabileceği sanılmaktadır. ${ }^{6}$

Anadolu Selçuklu mimarisinde uygulama alanı bulmayan tuğla-taş almaşıklığının Erken Dönem Osmanlı Mimarisi’nde görülmesinin nedeni, dikkate şayan bir konudur. Bu durum, Osmanlı Devleti'nin Bizans toprakları üzerinde kurulup, XIV. yy.'da hıla gelişmesi sırasında, bu medeniyetin ve kültürün unsurlarına mirasçı olmasının bir sonucu olmalidir.

6 Başgelen, 1993, 72. 
Özellikle 1204'te Konstantinopolis'in Latin işgaline uğramasıyla, merkezini İznik'e taşıyan Bizans Devleti, kendi yapı inşa tekniklerini kullanarak bu bölgede yoğun olarak imar faaliyetlerine girişmiş ve tuğla-taş almaşık örgülü çok sayıda örnek vermiştir. Yaklaşı bir yüzyıl sonra bu yöreye hâkim olan Osmanlıların mimaride tuğla-taş almaşık örgülü yapılar inşa etmesi, bir ilişkinin ve etkinin varlığını ortaya koymaktadır. ${ }^{7} \mathrm{Bu}$ etki süreci Bizans mimarlık öğelerinin tamamının adapte edilmesi şeklinde olmamıştır. XIV. yüzyılın ilk yarısında "aktarma ve aktarılanı yorumlama aşaması" görülürken, bu yüzyılın ikinci yarısında kendi aritmetik almaşıklık düzenini kurma ve bunun öteki yapı elemanlarıyla ilişkilerini yeniden yapılandırılması aşamasına geçilmiştir. ${ }^{8} \mathrm{Bu}$ durum, Geç Bizans ve Erken Osmanlı yapılarındaki almaşıklığın benzerlik ve farklılıklarının ortaya konulmasıyla anlaşılabilir.

Erken Osmanlı Dönemi'nde inşa edilen almaşık örgülü yapılarda taş, genellikle kaba yonu ve moloz olarak kullanılmaktadır. Osmanlı mimarisinde kullanılan tuğlalar ise gerek boyut gerekse biçim açısından Bizans tuğlalarından farklı değildir. Ancak tuğlaların boyutlarında dönemlere göre bazı değişiklikler meydana geldiği görülmektedir. İlk dönem yapılarında görülen tuğlalar çeşitli boyutlardadır. Ancak, genelde tuğlaların $14 \times 28 \mathrm{~cm}$ ve $30 \times 30 \mathrm{~cm}$ ölçülerinde, $4 \mathrm{~cm}$ ve nadiren $4,5 \mathrm{~cm}$ kalınlığında olduğu belirtilmektedir. ${ }^{9}$

$\mathrm{Bu}$ dönemde, duvar yüzeyinde tuğla-taş sırası tekrarlanma oranı çok az değişmektedir ve düzen aynı oranı devam ettirerek tutarlılık göstermektedir. Örneğin; dikey almaşıklığın basit uygulamalarından 3/1 düzende üç sıra tuğla, bir sıra taş malzeme kullanılarak belirli bir düzene göre tekrarlanarak duvar inşa edilmektedir. XIV. yüzyıl yapıları bu özelliğiyle Bizans almaşık duvarından ayrılmaktadır. Örneğin 14. yüzyılın ilk yarısında Osmanlı dikey almaşıklık sisteminin, tek sıra taş üzerine kurulduğu belirtilmektedir. ${ }^{10}$ Bizans mimarisinde bir sıra taş üzerine kurulan almaşık sistem başkent Konstantinopolis'te hemen hemen görülmez ancak iki, üç, hatta dört sıra taş örgüleri görülebilmektedir. Fakat başkent Konstantinopolis’ten uzak Arta, Mistra ve Selanik örneklerinde bir sıra taş üzerine kurulan dikey almaşıklık sistemi esastır. ${ }^{11}$

Erken Osmanlı Dönemi örneklerinde sık rastladığımız dikey almaşıklığın kompleks uygulamaları, Bizans kaynaklı etkinin varlığını ortaya koymaktadır. Bu uygulamanın bazı örneklerinde, $3 / 1,3 / 4,3 / 5$ olan tuğla-taş sıraları sonrasında $1 / 1$ düzen tekrarlanarak uygulanmaktadır. $\mathrm{Bu}$ bağlamda buradaki dikey almaşıklık kompleks örneklerinin genellikle erken dönemde bulunması bir rastlantı değildir. ${ }^{12}$ Taş sıraları

7 Batur 1970, 187.

8 Ersen, 1986, 44-45.

9 Ayverdi, 1966, 536.

10 Batur,1970, 191.

11 Ersen 1986, 45.

12 Sadece Erken Osmanlı Dönemi'nde görüldüğü söylenemez çünkü XVI. yüzyılda az sayıda örnekte görülmektedir. Örneğin, Köstendil Feridun Ahmet Bey Camii (1575) 3/2+2/1 düzendedir. 
arasına dikine yerleştirilen tuğlalarla oluşturulan yatay almaşıklık uygulaması da Bizans kaynaklıdır. ${ }^{13}$ Osmanlı mimarisinin erken dönem örneklerinde, daha çok bir ve/veya iki dikine tuğla uygulaması şeklinde karşımıza çıkar.

Erken Osmanlı dönemi almaşık duvarında, Bizans’ta olduğu gibi genellikle kaba yonu ve moloz taş kullanılması, derz yapım tekniğini de etkilemiştir. Taşları yatay düzleme paralel yerleştirilebilmek için geniş derz kullanımı yaygındır. ${ }^{14}$

Saçaklar, Bizans'ın karakteristiği haline gelen kirpi saçak şeklindedir. Erken örneklerde iki ve daha ziyade üç sıra kirpi saçak görülmektedir. Fakat görülen saçak kornişleri, Bizans örneklerine göre daha incedir. ${ }^{15}$ Ancak Erken Osmanlı dönemi kubbe kasnakları ise Bizans'tan farklı olarak tuğla-taş malzeme ile oluşturulmuş almaşık örgülüdür. Almaşık duvarın yineleme oranı genellikle kasnaklarda da aynı oranla sürdürülmektedir.

\section{Yüzyıl}

Osmanlı Devleti'nin kuruluş dönemini kapsar. Bu yüzyılın ilk yarısı Bursa'nın fethi (1326) ve İznik' in fethi (1331) ile başlayarak Güney Marmara'nın tamamen Osmanlı hâkimiyetine geçişine, ikinci yarısı Rumeli'ye geçiş (1354) ve Edirne'nin alınması (1361) sonrası Balkanlar'da hızlı bir genişlemeye tanık olmuştur. Bu nedenle yüzyılın ikinci yarısından itibaren devletin kurumsallaşması ve mali açıdan daha iyi olanaklara kavuşması yönünde belirli ilerlemenin kaydedildiği söylenebilir. ${ }^{16}$

Mimari açıdan bakıldığında bu yüzyılda kullanılan malzemenin niteliğinin iyi olduğu söylenemez. XIV. yüzyılda Osmanlı camilerinin hemen hemen tamamında malzeme olarak, tuğlanın yanında kaba yonu ve moloz taş yaygın kullanılmıştır. ${ }^{17}$ İncelenen 17 yapının on üçünde (\%76) kaba yonu taş-tuğla ve on ikisinde (\%70) ise moloz taş-tuğla malzeme kullanımı görülmektedir. Hem kaba yonu hem de moloz taş malzeme kullanılan yapı sayısı ise dokuzdur $(\% 53) .{ }^{18}$

Bundan başka, Tablo 1'deki veriler incelendiğinde kesme taşın nadir olarak yalnız birkaç yapıda kullanıldığı ve bu kullanımın da kaba yonu veya moloz taş ile birlikte olduğu görülmektedir. ${ }^{19}$ Bununla birlikte yapı cephelerinde tuğlanın yanında tek tip taş

13 Batur, 1970,191.

14 Ersen, 1986, 45.

15 Ersen, 1986, 47.

16 İnalc1k ve Quataert, 2000, 19.

1717 yapının 13'ünde kaba yonu taş-tuğla ve 12'sinde ise moloz taş-tuğla malzeme kullanılmıştır.

18 Bk. Tablo 1.

19 Bursa Orhan Camii'nde (1339-40) kesme-kaba yonu-moloz taş-tuğla, Bursa Hüdavendigar Camii'nde (1366) kesme-kaba yonu taş-tuğla ve Bursa Ali Paşa Camii'nde (XIV. yüzyıl ikinci yarıs1) kesme-moloz taş-tuğla malzeme kullanımı görülmektedir. 
malzemenin kullanılması ile duvar örgüsünün tamamlandığı örnekler enderdir. Kaba yonu taş-tuğla ve moloz taş-tuğla ile inşa edilen yapıların, bu yüzyıl boyunca yaygın görülüyor olması, malzeme kullanımı açısından herhangi bir iyileşme olmadığı algısına neden olmaktadır. Ancak XIV. yüzyılın geneline göre, özellikle I. Murad Dönemi’nden (1362-1389) itibaren malzeme kullanımında iyileşme görülür.

XIV. yüzyıla ait Osmanlı camilerinde dikey almaşıklığın hem basit hem de kompleks uygulamaları yaygındır. Dikey almaşıklığın basit uygulamaları tuğla ve taşın 4/1, 3/1, 2/1, 1/1 düzende alternatif sıralanışıyla meydana getirilmiştir. Bu uygulamalar arasında en yaygın olanı (17 yapının 10 tanesinde görülen), üç sıra tuğla, bir sıra taştan oluşan 3/1 düzendir. Bu uygulamayı, 6 yapıda görülen 1/1düzen, 4 yapıda görülen 2/1 düzen ve sadece iki yapıda gören 4/1 düzen takip etmektedir.

Kompleks uygulamalar ise 5 yapıda görülmektedir ve incelenen yapılar arasında en erken Bursa Alaeddin Camii'nde (1335) görülmektedir. Bursa Alaeddin Camii'nin batı cephesinde üç sıra tuğla, dört veya beş sıra taş ve 1 sıra tuğla ve 1 sıra taş şeklinde bir duvar örgüsü görülür.

Dikey almaşıklığın kompleks uygulamalarının görüldüğü diğer yapılar Bursa Orhan Camii (1339-40), Bilecik Orhan Gazi Camii (XIV. yy.'nn ilk yarısı), Bursa Kavaklı Camii (XIV. yy. ortaları) ve Bursa Hızırlık Camii'dir (XIV. yy'ın ikinci yarısı).

Bununla birlikte XIV. yüzyıl Osmanlı camilerinde yatay almaşı uygulamalarından 1 dikine tuğla kullanımı 13 yapıda, yani incelendiğimiz yapıların \%76'sında yaygın görülmektedir. 2 dikine tuğla ise sadece 4 yapıda görülmektedir. (Bk. Tablo 1)

Ayrıca bu yüzyılda kaba yonu ve moloz taş malzemenin yaygın kullanımına uygun olan geniş derz, 16 yapıda tercih edilmektedir; az sayıda örnekte ise kabarık harç (4 yapıda), çökertme derz (3 yapıda) ve yanaşık derz (2 yapıda) kullanılmıştır. (Bk. Tablo 1)

Yine bu yüzyılda kemerlerde de almaşı duvar örgüsüyle uyumlu bir uygulama olarak tuğla-taş malzeme kullanımı yaygındır. İnceleme kapsamındaki 17 yapıdan 11 'inde (\% 65) tuğla-taş kemer, 8 'inde $(\% 47)$ tuğla kemer ve 1 'inde $(\% 6)$ taş kemer tercih edilmiştir. (Bk. Tablo 1)

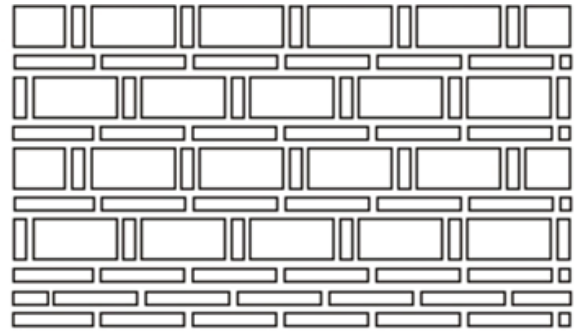

Şekil 7: Bursa Alaeddin Camii almaşık duvar örgüsü (dikey $3 / 1+1 / 1$, yatay 1 tuğla).

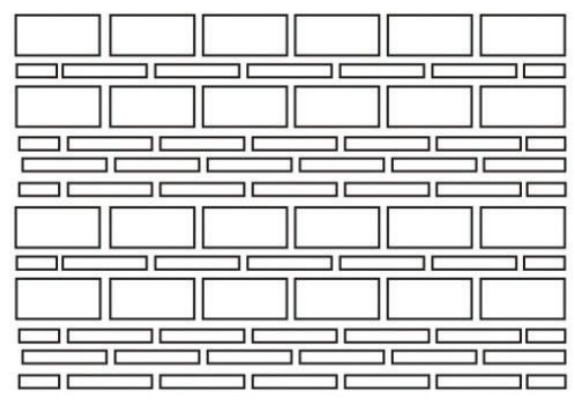

Şekil 8: Bilecik Orhan Gazi Camii almaşı duvar örgüsü (dikey $3 / 1+1 / 1$, yatay yok). 
Saçaklarda da benzer şekilde, almaşık duvar örgüsüne paralel uygulandığını bildiğimiz kirpi saçak uygulamaları çok yaygındır. Bu uygulamalar için özellikle sonraki dönemlerde onarım gören veya yeniden inşa edilen yapılarla karşılaşma ihtimali yüksektir. Bu nedenle şüpheye neden olabilecek saçak uygulamaları konusunda dikkatli yaklaşılmış ve bunlar tablolara işlenmemiştir. Örneğin 5 yapıda üç sıra kirpi saçak ve 4 yapıda iki sıra kirpi saçak uygulaması tespit edilmiştir. (Bk. Tablo 1)

Bununla birlikte incelediğimiz yapıların örtüsünü taşıyan kasnaklarının da almaşık duvar örgüsüyle tamamen uyumlu olacak biçimde çoğunlukla tuğla-taş malzemeyle yapılan almaşı örgüye sahip oldukları gözlenmiştir. 9 yapıda tuğla-taş örgü kasnak uygulaması görülürken sadece 1 yapıda taş örgü kasnak tercih edilmiştir. $\mathrm{Bu}$ yüzyıla ait olup da incelediğimiz yapılarda tuğla kasnak bulunmamaktadır. (Bk. Tablo 1)

\section{Yüzyll}

Bu yüzyıl, ilk yıllarında Timur karşısında meydana gelen Ankara Savaşı yenilgisi (1402) ve sonrasında şehzadeler arası taht kavgalarının yaşandığ1 "Fetret Devri” gibi ciddi olumsuzluklarla başlamasına rağmen, Osmanlılar açısından oldukça parlak bir şekilde tamamlanmıştır. Batı Anadolu Beylikleri’nin tekrar hâkimiyet altına alınması (1429) sonrasında özellikle 1448'de II. Kosova Savaşı ile Balkanlar'daki hâkimiyetin kesinleşmesi ve 1453 'te İstanbul'un fethi ile başlayan zaferler, 1461'de Trabzon Rum İmparatorluğu'na ve 1468'de Karamanoğulları hakimiyetine son verilerek taçlandırılmıştır. ${ }^{20}$ Siyasi yönden ve mali kaynaklar açısından meydana gelen olumlu değişisim, bu yüzyıla ait mimari eserlere de yansımıştır.

XV. yüzyıl, mimaride malzeme kullanımı açısından bir geçiş dönemi özelliği taşımaktadır. XIV. yüzyıla ait yapılarda, kaba yonu ve moloz taşın tuğla ile birlikte ağırlıklı olarak kullanımı, yerini XVI. yüzyılda çoğunlukla kesme taş-tuğla kullanımına bıraktığı için XV. yüzyıl bu iki uygulamanın dengelendiği bir döneme işaret eder. 32 yapıda (\%76) kaba yonu taş malzeme, 19 yapıda (\%45) kesme taş malzeme, 14 yapıda (\%33) ise moloz taş malzeme kullanımı söz konusudur. ${ }^{21}$ Bu yüzyılın ikinci yarısında, ilk yarıya oranla daha yoğun bir inşa faaliyeti dikkat çekmekte ve kullanılan malzemede belirli bir düzeyde iyileşme görülmektedir.

Dikey almaşıklığın basit uygulamaları açısından değerlendiğimizde, 1/1, 2/1, 3/1 ve 4/1 düzenler uygulanmış ve XIV. yüzyıl yapılarında \%58'i bulan bir oran ile görülen 3/1 düzen, bu yüzyıl yapılarında yaygınlığını korumuş ve görülme sıklığ1 \%64'e yükselmiştir. ${ }^{22}$ Ancak bir önceki yüzyıla ait yapılarda \%23 gibi düşük bir sıklıkla uygulanan 2/1 düzen ise XV. yüzyıl yapılarında \%71 gibi yüksek bir oranla hâkim konuma

20 İnalc1k ve Quataert, 2000, 19-20.

21 Bk. Tablo 2-A ve Tablo 2-B. 42 yapının 32'sinde kaba yonu, 19'unda kesme taş ve 14'ünde moloz taş malzeme kullanılmıştır.

22 Bk. Tablo 2-A ve Tablo 2-B. 42 yapının 27'sinde 3/1 sistem görülmektedir. 
ulaşmıştır. ${ }^{23}$ Yine XIV. yüzyıl yapılarında $\% 33$ oranında karşılaştığımız 1/1 düzen, bu yüzyllda $\% 10$ gibi bir orana gerilemiştir.

XV. yüzyılı kendi içerisinde ilk ve ikinci yarı şeklinde bir değerlendirmeye aldığımızda, dikey almaşıklığın basit uygulamalarının bazı farklı özellikler yansıttığı anlaşılmaktadır. Bu yüzyılın ilk yarısında 3/1 düzen tuğla-taş almaş̧ılı̆̆ı XIV. yüzyılda da olduğu gibi 2/1 düzenden daha sık uygulanmıştır. Ancak yüzyılın ikinci yarısında 2/1 düzenin 3/1 düzenden daha yaygın hale geldiği ve yukarıda yaptığımız değerlendirmede de belirttiğimiz gibi XV. yüzyıla ait Osmanlı camilerinde $\% 65$ 'e varan bir yaygınlığa ulaştığı görülür.

XV. yüzyılda yatay almaşılık uygulamalarında da XIV. yüzyıla göre bazı farklılıklar görülmektedir. Yatay almaşıklık örneklerinde iki dikine tuğla kullanımı, XIV. yüzyıla göre önemli bir artış göstererek $\% 16$ 'dan $\% 40$ 'a ulaşmış olmasına rağmen, $\% 45$ oranındaki bir dikine tuğla kullanımını geçmeyi başaramamıştır. Ancak bu yüzyılın ilk yarısında bir dikine tuğla kullanımı, ikinci yarısında ise iki dikine tuğla kullanımı yoğun olarak görülmektedir.

Ayrıca XIV. yüzyılda olduğu gibi geniş derzin çok açık bir şekilde üstünlüğü devam ederken, kabarık harca da önceki yüzyıla oranla daha sık rastlanmaktadır. Bununla birlikte incelenen yapılarda iki sıra kirpi saçak uygulaması \%60'1 geçen bir sıklıkla bu yüzyıla damgasını vuran özelliklerden biri olmuştur.

XIV. yüzyılda herhangi bir örneğini bilmediğimiz taş saçak uygulaması, bu yüzyılda \%20'ye varan bir oranla ortaya çıkmıştır. Başlangıcından XV. yüzyılın ortalarına kadar almaşık duvara daima kirpi saçak eşlik etmiştir. ${ }^{24} \mathrm{Bu}$ nedenle almaşık örgülü yapılarda taş saçağın uygulanması biraz düşündürücüdür. Bu durum, incelenen yapıların büyük çoğunluğunda üst yapı onarımlarının yapılmış olabileceğini akla getirmektedir. Saçaklar konusunda çok dikkatli olunması gerekmektedir. Bu nedenle XV. yüzyıl için bir genelleme yapmanın yanıltıcı olacağı kanısındayız. Bununla birlikte, kasnaklarda taştuğla kullanımı, bir önceki yüzyılda olduğu gibi yaygın, tercih edilen uygulama olma konumunu tartışmasız sürdürmüştür. ${ }^{25}$

\section{Değerlendirme}

Anadolu Selçuklu dönemi yapılarının duvar örgüsünde karşımıza çıkmayan tuğla-taş almaşıklı̆̆ 1 , kurulduğu coğrafyada kendisine intikal eden Bizans mimari mirasının da bir sonucu olarak, Osmanlılara ait XIV. yüzyıl yapılarında en yaygın duvar örgü tekniği olarak ortaya çıkmıştır. Bu durum, bazı araştırmacılar tarafından Bursa ve çevresinin yeterli kalite ve bollukta taş kaynaklarına sahip olmamasıyla ve Osmanlı Devleti’nin bu yüzyılda mali yönden çok iyi koşullara sahip olmaması gibi nedenlerle

23 Bk. Tablo 2-A ve Tablo 2-B. 42 yapının 30'unda 2/1 sistem görülmektedir.

24 Batur, 1970, 202.

25 Bk. Tablo 2-A ve Tablo 2-B. 42 yapının otuz beşinde kasnak tuğla-taş almaşık örülmüştür. 
açıklanmaya çalışılmıştır. Taş kaynaklarının sınırlılığı ile ilgili görüş, doğal koşulların dönem farkı gözetmeksizin Bursa ve çevresinin mimarisini belirleyen ve sınırlayan bir özelliğe sahip olduğu noktasına dayanmaktadır. Bu özellik aynı zamanda sınırlı mali kaynak ve olanakların söz konusu olmasıyla birlikte daha da güçlü etki yapmaktadır. Bahsedilen doğal ve mali sınırlılıklar bu yörede moloz taş, tuğla ve kerpiç malzemeyle inşa edilmiş yapılarla karşılaşmamızı açıklamaya yeterli dayanak oluşturabilirken, belirli bir düzen ve teknikle uygulanan tuğla-taş almaşıklığının görülmesini açıklamakta yetersiz kalmaktadır. İşte bu noktada, son dönem Bizans yapılarında çok yaygın görülen almaşık duvar örgü ve tekniklerinden Osmanlıların bir çözüm olarak yararlanması durumu açıklayıcı olmaktadır.

Genel olarak XIV - XV. yüzyıllarda Osmanlı camilerinde görülen almaşık duvar örneklerinde tuğla ve her üç haliyle (kesme, kaba yonu, moloz) taş malzemelerin birlikte kullanıldığ 1 görülmektedir. Ancak bu durum almaşıklığın dikey ve yatay uygulanmasına göre farklı görünümler ortaya çıkarmıştır. Detaylı bakıldığında dikey almaşıklığın basit düzen uygulamalarında taşın türü ve formu ne olursa olsun, duvar örgüsünde tuğlalar arasındaki taş sıralarının tek oluşu önemlidir ve çok yaygındır. Bununla birlikte daha az sayıda yapının duvar örgüsünde birden fazla taş sırası olduğu görülmüştür. Bu yapılarda duvar örgüsü genellikle dikey almaşık kompleks düzen uygulamalarıyla örülmüştür.

Bununla birlikte incelenen yapıların malzeme kullanımı değerlendirildiğinde, öncelikle XIV. yüzyılda yoğunlukla kaba yonu ve moloz taş kullanımı görülür. Ancak bu yüzyılın ikinci yarısında malzeme niteliğinde bir iyileşme görülmeye başlamıştır. XV. yüzyılda çok daha belirgin hale gelen bu iyileşme, özellikle kesme taş kullanımının artması şeklindedir. Bu gelişme XVI. yüzyılda, Osmanlı Devleti'nin altın çağı olmasının bir sonucu olarak, malzemede zirveye ulaşılmasıyla kendini görünür kılmaktadır.

Almaşıklığın dikey, yatay ve bileşik türde uygulamaları XIV - XV. yüzyıl Osmanlı camileri bağlamında ele alındığında ilginç sonuçlara ulaşılmıştır. Örneğin, dikey almaşıklığın basit düzen uygulamalarında gözlemlenen gelişme ve değişimleri şöyle özetleyebiliriz: XIV. yüzyılda en çok 3/1 düzen görülürken, XV. yüzyılda 2/1 düzen daha sık uygulama alanı bulmuştur. Ortaya çıkan sonuçlar ile daha önce yapılan çalışmaların sonuçları arasında bir karşılaştırma yapmak gereklidir.

Batur, çalışmasında XIV. yüzyıla ait 12 yapıyı incelemiş, bunların dokuzunda (\%75) 3/1 düzen, dördünde (\%33) 1/1 düzen, ikisinde (\%17) ise 4/1 düzen dikey almaşıkliğın basit uygulamaları bulunduğunu tespit etmiştir. Ancak 2/1 düzeni ise hiçbir yapıda gözlemlememiştir. ${ }^{26} \mathrm{Bu}$ çalışmamızla ulaşılan sonuçlar ise şöyledir: XIV. yüzyıla ait olup, incelenen 17 yapının onunda (\%58) 3/1 düzen, altısında (\%35) 1/1 düzen, dördünde (\%23) 2/1 düzen ve ikisinde (\%11) 4/1 düzen dikey almaşıklığın basit uygulamaları gözlemlenmiştir. (Bk. Tablo 1) Bu sonuçlarda en dikkat çekici fark, hiçbir yapıda gözlenmediği belirtilen $2 / 1$ düzenin dört adet yapıda varlığının tespitidir.

26 Batur, 1970, 173. Bk. Tablo. 


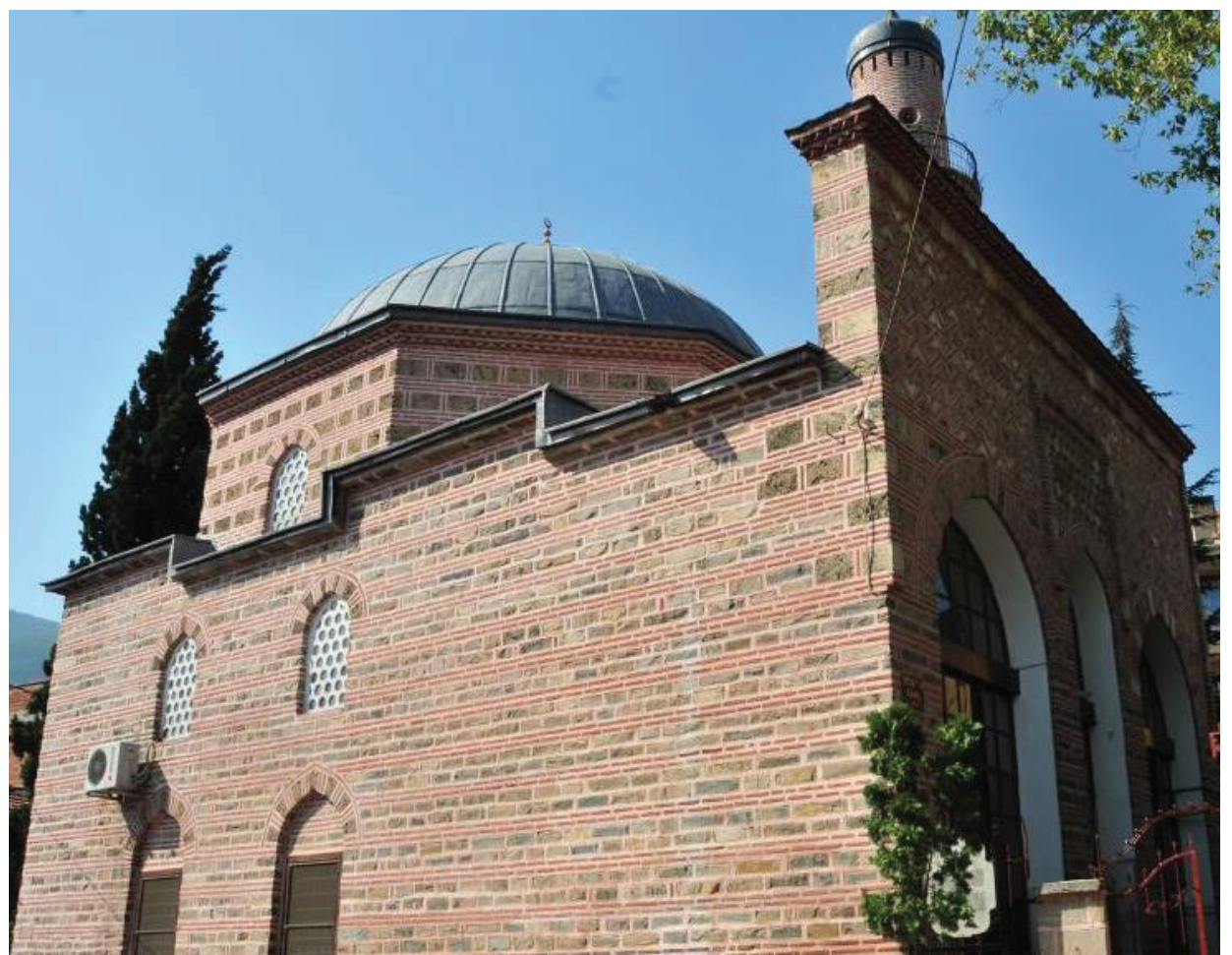

Fotoğraf 2: Bursa Bedrettin (Hafsa Sultan) Camii. (1443) (www.kulturportali.gov.tr)

Batur'un çalışmasında, XV. yüzyıla ait 33 yap1 incelenmiş; bunların yirmisinde (\%61) 3/1 düzen, on dokuzunda (\%58) 2/1 düzen ve dördünde (\% 12) 1/1 düzen dikey almaşıklığın basit uygulamaları tespit edilirken; 4/1 düzene hiçbir yapıda rastlanmamıştır. ${ }^{27} \mathrm{Bu}$ çalışmamızın sonuçları ise şöyledir: İncelenen 42 yapının otuzunda (\%71) 2/1 düzen, yirmi yedisinde (\%64) 3/1 düzen, beşinde (\%12) 1/1 düzen ve üçünde (\%7) 4/1 düzen dikey almaşıklığın basit uygulamaları gözlenmiştir. (Bk. Tablo 2-A ve 2-B) Karşılaştırmada en dikkat çekici fark XV. yüzyılda 2/1 düzenin 3/1 düzenden daha sık görülmesidir. Bununla birlikte yukardaki verilerine göre XIV. yüzyılda hiç görülmeyen 2/1 düzen dikey almaşıklık, XV. yüzyılda on dokuz yapıda aniden ortaya çıkmıştır. Oysa bu değişimin sürecini, yaptığımız çalışma açıkça ortaya koymaktadır. Öncelikle 2/1 düzenin XIV. yüzyıla ait dört yapıda varlığı tespit edilmiş; XV. yüzyılın ilk yarısında 3/1 düzeni görülme sıklığı açısından yakalamış, XV. yüzyılın ikinci yarısında ise $3 / 1$ düzeni geride bırakarak öne geçmiştir. Sonuçta; bu yüzyıla ait 42 yapının otuzunda 2/1 düzen, yirmi yedisinde ise 3/1 düzen uygulanmıştır.

27 Batur, 1970, 173. Bk. Tablo. 
Bizans’tan alındığg düşünülen dikey almaşıklığın kompleks uygulamaları en çok XIV. yüzyıla ait yapılarda ve özellikle de Orhan Gazi dönemi yapılarında gözlemlenmiştir. Bu yüzyılın ilk yarısında dört yapıda, ikinci yarısında ise bir yapıda karşılaşılmıştır. (Bk. Tablo 1) Malzeme kalitesinin artışı ve dikey almaşıklığın basit düzenlerinin sistematik uygulanması sürecinde kompleks uygulamalar oldukça azalmıştır. Bu sonuçlar, daha önceki çalışmaların sonuçlarıyla uyumludur. Batur, XIV. yüzyılın ilk yarısında üç yapıda, ikinci yarısında ise bir yapıda kompleks düzen gözlemlemiştir. ${ }^{28}$

Bu çalışma kapsamında ele alınan diğer bir husus yatay almaşıklık örnekleridir. Bizans kaynaklı olduğu düşünülen ancak Bizans'ın başkent yapılarında tercih edilmeyen yatay almaşıklık, XIV - XV. yüzyıl Osmanlı camilerinde gözlenebilen bir özelliktir. Bu zaman dilimi içerisinde bu tekniğin izlediği seyir şöyle özetlenebilir: XIV. yüzyılda bir dikine tuğla, incelenen 17 yapının on üçünde (\%76) yani dörtte üçünde görülürken, iki dikine tuğla ise dört yapıda (\%24), yani dörtte birinde görülmektedir. (Bk. Tablo 1) Batur'un çalışmasındaki sonuçlar ise incelenen 12 yapının altısında (\%50), yani yarısında, bir dikine tuğla ve sadece iki yapıda (\%17) iki dikine tuğla görülmektedir. ${ }^{29}$ Sonuçlar arasında dikkat çeken fark ise yatay almaşıklığın görülme sıklığıdır. Daha önceki çalışmanın sonuçlarına göre 12 yapının yedisinde $(\% 58)$ yatay almaşıklık görülürken, yaptığımız çalışmada ele alınan 17 yapıdan on üçünde (\%76) yatay almaşıklık tespit edilmiştir. Ayrıca daha önceki çalışmada yatay almaşıklık tespit edilen 7 yapıdan sadece birinde hem bir dikine tuğla hem de iki dikine tuğla kullanımı vardır. Çalışmamızda ise, yatay almaşıklık bulunduğu tespit edilen 13 yapının dördünde hem bir dikine tuğla hem de iki dikine tuğla kullanımı vardir. (Bk. Tablo 1)

XV. yüzyılda yatay almaşıklıkta farklılıklar gözlenmiştir. Batur'un çalışmasında ele alınan 33 yapının on yedisinde (\%51) bir dikine tuğla ve yedisinde $(\% 21)$ ise iki dikine tuğla kullanımının tespiti yapılmıştı. ${ }^{30} \mathrm{Bu}$ çalışmada ele alınan 42 yapının on sekizinde $(\% 43)$ bir dikine tuğla ve on dokuzunda (\%45) iki dikine tuğla kullanımı görülmüştür. (Bk. Tablo 2-A ve 2-B) İki çalışmanın ortaya koyduğu en önemli fark iki dikine tuğlanın görülme sıklığına dairdir. Daha önceki çalışmada bir dikine tuğla daha sık görülmesine rağmen, bu çalışmamızın sonucuna göre iki dikine kullanımının önemli bir artış gösterdiği ve her iki kullanımın başa baş gittiği söylenebilir.

Bununla birlikte daha önceki çalışmada incelenen 33 yapının yirmisinde (\%61) yatay almaşıklık görülmüştür. Bu yirmi yapının dördünde hem bir dikine hem iki dikine tuğla kullanımları tespit edilmiştir. ${ }^{31} \mathrm{Bu}$ çalışmanın sonuçlarına göre ele alınan 42 yapının otuz beşinde (\%83) yatay almaşıklık gözlemlenmiştir. Söz konusu 35 yapının dördünde ise hem bir dikine tuğla hem de iki dikine tuğla kullanımı vardır. Sonuçta yatay almaşıklığın \%83 gibi daha yüksek oranda görüldüğü ortaya çıkmıştır. (Bk. Tablo 2-A ve 2-B)

28 Batur, 1970, 173. Bk. Tablo.

29 Batur, 1970, 173. Bk. Tablo.

30 Batur, 1970, 173. Bk. Tablo.

31 Batur, 1970, 173. Bk. Tablo. 
İncelenen yapıların duvar örgüsünde ele alınan diğer bir unsur derz özellikleridir. Kaba yonu ve moloz taş gibi düzgün olmayan malzemeyle örülen duvarda taş ve tuğla sıralarını düzleştirmek için uygulanan geniş derz, XIV ve XV. yüzyıllar için hâkim derz uygulamasıdır. Daha önceki çalışmaların ulaştığı sonuçlar ile bu çalışmada uyumlu sonuçlara ulaşılmıştır. XIV. yüzyıla it 12 yapının onunda (\%83) ve XV. yüzyıla ait 33 yapının yirmi dokuzunda (\%88) geniş derz tespit edilirken; ${ }^{32}$ bu çalışmada ise ele alınan XIV. yüzyıla ait 17 yapının on altısında (\%94) ve XV. yüzyıla ait 42 yapının otuz dokuzunda (\%93) geniş derz görülmüş̧ür. (Bk. Tablo 2-A ve 2-B)

Bununla birlikte bu çalışma kapsamında almaşık duvar örgüsünün tamamlayıcı unsurlarından biri olan kemerlerde malzeme seçimi dikkat çekmektedir. Bu çalışmanın sonuçlarına göre XIV. yüzyılda incelenen 17 yapının on birinde (\%65) tuğla-taş kemer, sekiz yapıda (\%47) tuğla kemer ve bir yapıda (\%6) ise taş kemer tercih edildiği görülmektedir. (Bk. Tablo 1) Daha önceki çalışmada incelenen 12 yapının dokuzunda (\%75) tuğla-taş kemer, dördünde (\%33) tuğla kemer ve birinde (\%8) ise taş kemer bulunmuştur. ${ }^{33}$ Sonuçlar birbiri ile tutarlıdır ve aralarındaki fark genel görünümü değiştirmemektedir.

Ayrıca XV. yüzyıla ait olup, incelenen 42 yapının yirmi dokuzunda (\%69) tuğlataş kemer, yirmi yedisinde (\%64) tuğla kemer ve birinde (\%2) taş kemer tespit edilmiştir. (Bk. Tablo 2-A ve 2-B) Daha önceki çalışmanın incelediği, bu yüzyıla ait 33 yapının yirmi birinde (\%64) tuğla-taş kemer, on dördünde (\%42) tuğla kemer ve ikisinde (\%6) taş kemer bulunmaktadır. ${ }^{34}$ Sonuçlar yine birbiriyle tutarlıdır ancak bazı rakamlarda fark çıkmıştır.

Tuğla-taş almaşık duvar örgüsü ile yakın ilişkileri dolayısıyla saçak ve kasnaklardaki gelişme ve değişimler de çalışma kapsamında incelenmiştir. Öncelikle XIV. yüzyıl Osmanlı camilerinin saçaklarında, Bizans döneminin de karakteristiği olan kirpi saçak veya testere saçak uygulamaları görülmektedir.

XIV. yüzyıla ait yapıların özgün saçak özelliğini koruyanlarından hareketle yapılan incelemede 17 yapının beşinde (\%29) üç sıra kirpi saçak ve dördünde (\%24) iki sıra kirpi saçak tespit edilmiştir. (Bk. Tablo 1) Daha önceki çalışmada ise 12 yapının beşinde (\%42) üç sıra ve ikisinde (\%17) iki sıra kirpi saçak kaydedilmiştir. ${ }^{35}$

XV. yüzyılda saçak uygulamaları ise incelenen 42 yapıdan otuzunda (\%71) iki sıra kirpi saçak, altısında (\%14) üç sıra kirpi saçak, sekizinde (\%19) taş korniş ve birinde de bir sıra kirpi saçak şeklinde tespit edilmiştir. (Bk. Tablo 2-A ve 2-B) Daha önceki çalışma ise, incelenen 33 yapının on altısında (\%48) iki sıra kirpi saçak, dördünde (\%12) üç sıra kirpi saçak, üçünde (\%9) taş saçak ve birinde bir sıra kirpi saçak bulunduğunu

32 Batur, 1970, 173. Bk. Tablo.

33 Batur, 1970, 173. Bk. Tablo.

34 Batur, 1970, 173. Bk. Tablo.

35 Batur, 1970, 173. Bk. Tablo. 
Mehmet Kutlu

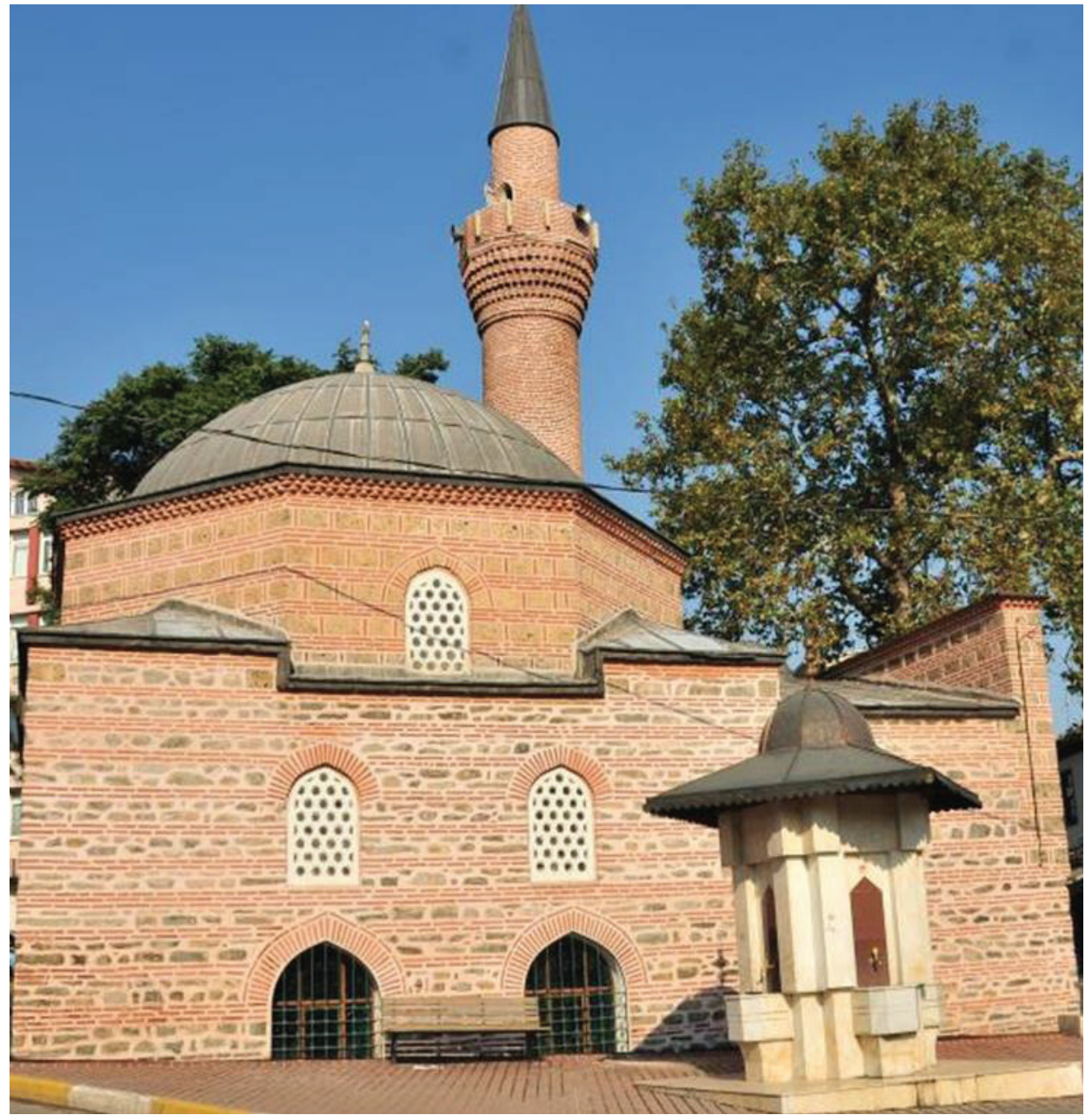

Fotoğraf 3: Bursa, Yiğit Köhne Camii. (www.kulturportali.gov.tr) 
göstermektedir. ${ }^{36}$ Her iki çalışmada da iki sıra kirpi saçak en çok tercih edilen uygulama olmasına rağmen görülme sıklıkları farklılık göstermektedir. Bununla birlikte yüzyılda en dikkat çekici gelişme kesme taş kullanımında meydana gelen artışla birlikte taş saçak uygulamasının yavaş yavaş görünürlüğünün artmasıdır.

XIV. yüzyıl yapılarının kubbe kasnaklarına bakıldığında tuğla-taş malzemeyle almaşık olarak örüldükleri görülür. İncelenen 17 yapının dokuzunda (\%53) tuğla-taş almaşık kasnak, birinde (\%6) taş kasnak tespit edilmiştir ancak hiçbir yapıda tuğla kasnak görülmemiştir. (Bk. Tablo 1) Bu sonuçlar daha önceki çalışmaların sonuçlarıyla tutarlıdır: Batur incelediği 12 yapının dokuzunda (\%75) tuğla-taş kasnak, birinde (\%8) taş kasnak tespit ederken, hiçbir yapıda tuğla kasnak tespit etmemiştir. ${ }^{37} \mathrm{Bu}$ sonuç, Bizans mimarisinde karakteristik olarak görülen tuğla kasnak uygulamasına tezat bir durumdur.

Bununla birlikte, incelenen, XV. yüzyıla ait 42 yapının otuz beşinde (\%83) tuğla-taş, üçünde tuğla ve birinde ise taş kasnak gözlemlenmiştir. (Bk. Tablo 2-A ve 2-B) Daha önceki çalışmanın ulaştığı sonuçlar ise şöyledir: 33 yapının on dördünde (\%42) tuğla-taş kasnak, birinde (\%3) tuğla kasnak bulunurken, hiçbir yapıda taş kasnak kaydedilmemiştir. ${ }^{38}$ Sonuçlar arasında fark görülmesine rağmen genel durum benzerdir.

\section{Sonuç}

$\mathrm{Bu}$ çalışma, daha önce yapılan çalışmalarda ulaşılan sonuçlar ile yaptığımız gözlemler sırasında karşılaşılan farklılıklardan hareketle yapılmıştır. Örneğin, daha önce yapılan çalışmalara göre XIV. yüzyılda görülmediği ve XV. yüzyılda birden bire ortaya çıktığı belirtilen 2/1 düzende dikey tuğla-taş almaşıklı̆ının, bu inceleme sonucunda, aslında XIV. yüzyıla ait yapılarının dördünde (\%24) bulunduğu anlaşılmışıtı. Yani 2/1 düzen dikey almaşıklık XV. yüzyılda ortaya çımamış ve aniden 3/1 düzenden 2/1 düzene geçiş başlamamıştır. Hatta bu değişimin XV. yüzyılın ilk ve ikinci yarısında nasıl bir yol izlediği de ortaya çıkmıştır. XV. yüzyılın ilk yarısında $2 / 1$ düzen dikey almaşıklık ciddi bir artış kaydetmiş olmasına rağmen 3/1 düzeni geçememiş fakat ikinci yarıda 3/1 düzenin önüne geçmiş ve hatta XV. yüzyllın genelinde en çok tercih edilen dikey almaşıklık uygulaması haline gelmiştir.

Daha önceki çalışmalarda incelenen XV. yüzyıla ait 33 adet yapının sadece ikisinde (\%7) görülen kesme taş-tuğla almaşıklığı, bu çalışmada incelenen ve aynı yüzyıla tarihlenen 42 adet yapının 19'unda (\%45) görülmektedir. Daha önceki çalışmalarda tespiti yapılan söz konusu iki yapının da yüzyılın ilk yarısına ait olmasına karşın, yüzyılın ikinci yarısına ait hiçbir yapıda kesme taş-tuğla almaşık duvar örgüsü tespit edilememiştir. Oysa bu yüzyılın ikinci yarısında ilk yarıya nazaran daha çok kesme taş-tuğla almaşık örgülü

36 Batur, 1970, 173. Bk. Tablo.

37 Batur, 1970, 173. Bk. Tablo.

38 Batur, 1970, 173. Bk. Tablo. 
yapı inşa edildiği anlaşılmıştır. ${ }^{39}$ Diğer bir deyişle, kesme taş malzeme kullanımı Osmanlı Devleti'nin altın çağı olan XVI. yüzyılda birden bire patlama yaparak ortaya çıkmamış, XV. yüzyılda belirli bir artış süreci takip ederek yaygınlık kazanmıştır.

Bununla birlikte daha önceki bazı çalışmalarda 4/1 dikey tuğla taş almaşıklığın XV. yüzyıl Osmanlı camilerinde görülmediği belirtilirken bu çalışma sonucunda üç adet yapıda 4/1 düzen dikey tuğla taş almaşık duvar örgüsü tespit edilmiştir.

Yukarıda verdiğimiz detaylar ile belirginleşen önemli bir husus; daha fazla sayıda yapı ve bunların özgün niteliklerinin korunup korunmadığı konusunda yapılacak titiz seçim ve eleme ile oluşturulacak bir veri tabanı ile daha derinlemesine analiz ve daha tutarlı sonuçlara ulaşmanın mümkün olacağıdır. XIV - XV. yüzyıllara ait Osmanlı camilerinde görülen almaşık duvar örgüsü ve niteliği üzerine son noktayı koyma iddiasında olmayan bu çalışma, malzeme kullanımı ve inşa teknikleri konusunda daha geniş kapsamlı çalışmaların yapılması gerekliliğini vurgulamayı da amaçlamıştır.

39 Yüzyılın ilk yarısında 7 yapıda, ikinci yarıda ise 12 yapıda kesme taş-tuğla almaşık duvar görülmektedir. (Bk. Tablo 2A ve 2B). 


\section{KAYNAKÇA}

Acun, H. (1999), Manisa'da Türk Devri Yapılarl, Ankara: Türk Tarih Kurumu.

Aktuğ-Kolay, İ. (1999), Batı Anadolu 14. Yüzyll Beylikler Mimarisinde Yapım Teknikleri, Ankara: Atatürk Kültür Merkezi Başkanlığı.

Ayverdi, E.H. (1966), Osmanl Mimarisinin İlk Devri I, İstanbul: İst. Fetih Cemiyeti.

Ayverdi, E.H. (1972), Osmanlı Mimarisinde Çelebi ve II. Sultan Murad Devri 806-855 (1403-1451), İstanbul: İstanbul Fetih Cemiyeti.

Ayverdi, E.H. (1974), Osmanl Mimarisinde Fatih Devri 855-886 (1453-1481), İstanbul: İstanbul Fetih Cemiyeti.

Ayverdi, E.H. (1981), Avrupa'da Osmanlı Mimari Eserleri: Yugoslavya, İstanbul: İstanbul Fetih Cemiyeti.

Ayverdi, E.H. (1982), Avrupa'da Osmanl Mimari Eserleri: Bulgaristan, Yunanistan, Arnavutluk, İstanbul: İstanbul Fetih Cemiyeti.

Başgelen, N. (1993), Çağlar Boyunca Anadolu'da Duvar, İstanbul: Türk Ytong Sanayi.

Batur, A. (1970), Osmanlı Camilerinde Almaşık Duvar Üzerine, Anadolu Sanatı Araştırmaları II, İstanbul, 135-216.

Bayrakal, S. (2001), Edirne'deki Tek Kubbeli Camiler, Ankara: Kültür Bakanlığı.

Beşbaş, N. - Denizli, H., (1983) Türkiye'de Vakıf Abideler ve Eski Eserler III, Ankara: Vakıflar Genel Müdürlüğü.

Ersen, A. (1986), Erken Osmanll Mimarisinde Cephe Biçim Düzenleri ve Bizans Etkilerinin Niteliği. İstanbul: İTÜ Mimarlık Fak.

Ersoy, B. (1989), Bergama Cami ve Mescitleri, Ankara: Kültür Bakanlığı.

Gabriel, A. (1958) Une Capitale Turque Brousse Bursa. Paris: E.de Boccard.

İbrahimgil, M.Z., Konuk, N. (2006), Kosova'da Osmanlı Mimari Eserleri, Ankara: Türk Tarih Kurumu.

İnalc1k, H. - Quataert, D. (2000), Osmanlı İmparatorluğu'nun Ekonomik ve Sosyal Tarihi I: 1300-1600, İstanbul: Eren Yayınc1lı.

Öz, T. (1962), İstanbul Camileri, İstanbul: Türk Tarih Kurumu. 
Özer, M. (2006), Üsküp’te Türk Mimarisi, Ankara: Türk Tarih Kurumu.

Sözen, M. - Tanyeli, U. (2003) Sanat Kavram ve Terimleri Sözlüğü, İstanbul: Remzi Kitapevi.

Şener Y.S. (1993), XIV. Yüzyıl Bursa Yapılarında Erken Osmanlı Duvar Örgüsü. Ankara Üniversitesi, Yayınlanmamış Yüksek Lisans Tezi, Ankara.

Tunay, M.İ. (1983), Geç Bizans-Erken Osmanlı Duvar Teknikleri. VIII. Türk Tarih Kongresi (11-15 Ekim 1976), C. III, s.1691-1696.

Turan, Ö. - İbrahimgil, M. Z. (2004), Balkanlarda Türk Mimari Eserlerinden Örnekler, Ankara: TBMM Kültür, Sanat ve Yayın Kurulu.

Yüksel, İ. A. (1983), Osmanlı Mimarisinde II. Bayezid, Yavuz Selim Devri, İstanbul: İstanbul Fetih Cemiyeti.

\section{Yararlanılan İnternet Siteleri}

http://www.kulturportali.gov.tr/turkiye/bursa/kulturenvanteri/bedrettin-hafsa-sultan-camii

http://www.kulturportali.gov.tr/turkiye/bursa/kulturenvanteri/yigit-kohne-camii 


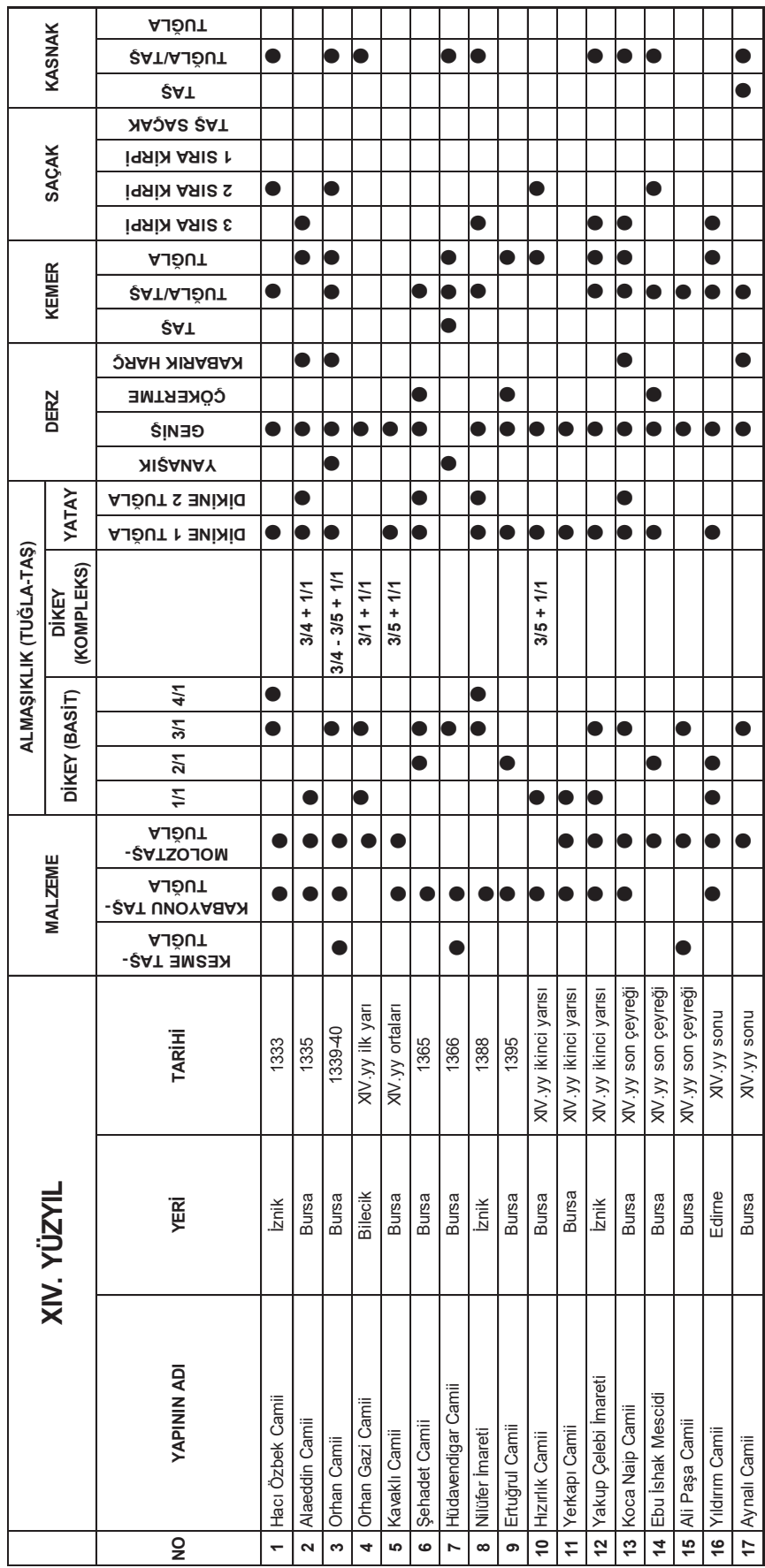




\begin{tabular}{|c|c|c|c|c|c|c|c|c|c|c|c|c|c|c|c|c|c|c|c|c|c|}
\hline \multirow{3}{*}{$\begin{array}{l}\text { r } \\
\mathbf{S} \\
\text { \$ }\end{array}$} & 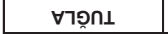 & & 0 & & & & & & & & & & & & & & & & & & \\
\hline & 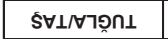 & & & 0 & & & $\bullet$ & 0 & - & - & 0 & - & - & - & $\bullet$ & - & 0 & 0 & & - & 0 \\
\hline & $\delta \forall \perp$ & & & & - & & & & & & & & & & & & & & & & \\
\hline \multirow{4}{*}{ 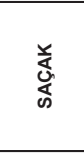 } & 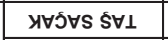 & & & - & $\bullet$ & - & & & & & & & & & & & 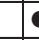 & 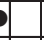 & & & 0 \\
\hline & 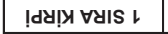 & & & & & & & & & & & & & & & & & - & & & \\
\hline & 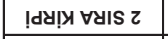 & - & - & & & & - & 0 & - & - & - & - & & - & $\bullet$ & - & & - & - & & \\
\hline & 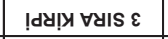 & & & & & & & & & & & & & & & - & - & & & - & \\
\hline \multirow{3}{*}{ 䍃 } & $\forall า อ ุ ก \perp$ & & 0 & - & $\bullet$ & 0 & & 0 & 0 & - & 0 & & 0 & 0 & & & - & & 인 & 0 & 0 \\
\hline & ร์เ/จาอุกเ & $\bullet$ & $\bullet$ & - & & $\bullet$ & - & & $\bullet$ & 0 & 0 & - & & & $\bullet$ & - & - & $\bullet$ & & 0 & - \\
\hline & $\delta \forall \perp$ & & & & & & & & & & & & & & & & 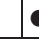 & 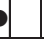 & & & \\
\hline \multirow{4}{*}{ 咅 } & 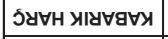 & & 0 & & $\bullet$ & $\bullet$ & - & & & & & & & - & & & - & - & & - & $\bullet$ \\
\hline & 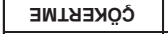 & & & & & & & & & & & & & & & & & & & & \\
\hline & §!̣Nヨอ & - & - & - & - & - & - & 0 & & - & - & - & - & - & - & - & - & - & - & - & $\bullet$ \\
\hline & 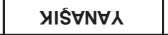 & 0 & - & & & & & & 0 & & & & & & & & 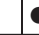 & 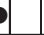 & & & \\
\hline \multirow{2}{*}{ 忞 } & 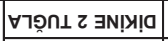 & & 0 & 0 & & & & 0 & & 0 & & 0 & 0 & & & & - & & 0 & 0 & \\
\hline & 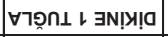 & & 0 & & & 0 & 은 & & - & & 0 & - & & - & 0 & - & & & & - & \\
\hline 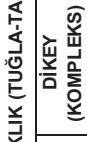 & & & & & & & & & & & & & & & & & & & & & \\
\hline \multirow{4}{*}{$\begin{array}{l}\frac{E}{9} \\
\frac{a}{0} \\
\frac{9}{\dot{y}} \\
\frac{\underline{y}}{0}\end{array}$} & ร & & & & & & & & & & & & & & & & - & & & & \\
\hline & 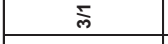 & - & - & - & - & $\bullet$ & - & & - & & - & - & & & & - & - & & - & - & \\
\hline & $\frac{2}{4}$ & & & $\bullet$ & & & - & - & 0 & 0 & $\bullet$ & - & 0 & & 0 & 0 & - & 0 & & 0 & 0 \\
\hline & 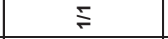 & & & & & & & & & & & - & & $\bullet$ & & & & & & & \\
\hline \multirow{3}{*}{ 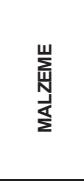 } & 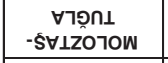 & & - & & & - & - & & - & & & & & - & & & & & & - & \\
\hline & 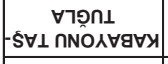 & • & - & & & - & - & & - & 이 & 0 & - & - & - & 0 & 0 & - & - & - & - & 0 \\
\hline & 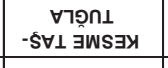 & - & - & - & D & & & ? & • & - & & & & & - & - & & $\bullet$ & & & \\
\hline \multirow{4}{*}{ 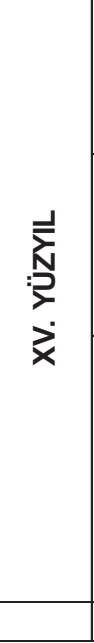 } & $\frac{\overline{\underline{T}}}{\frac{\bar{\alpha}}{5}}$ & 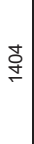 & 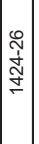 & 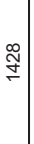 & 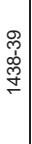 & $\frac{\mathfrak{Z}}{\mathcal{Z}}$ & $\frac{m}{g}$ & $\mid \begin{array}{l}\frac{3}{4} \\
\frac{3}{5}\end{array}$ & 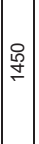 & 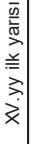 & 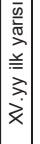 & 兽 & $\begin{array}{l}\stackrel{\leftrightarrow}{g} \\
\leftarrow\end{array}$ & 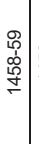 & 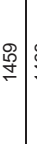 & $\begin{array}{l}\infty \\
\stackrel{o}{\sigma} \\
\leftarrow\end{array}$ & \begin{tabular}{lll}
0 \\
\hdashline \\
\hdashline
\end{tabular} & 殀 & 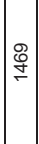 & $\stackrel{\tilde{\hat{\sigma}}}{\leftarrow}$ & $\underset{\tilde{f}}{\sigma}$ \\
\hline & 趈 & 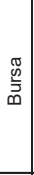 & 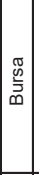 & 竞 & 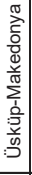 & 岛 & 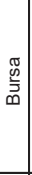 & 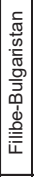 & 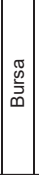 & 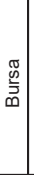 & 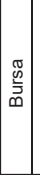 & 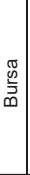 & 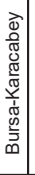 & 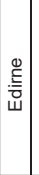 & . & 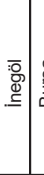 & & 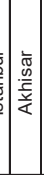 & 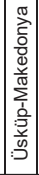 & & 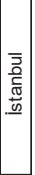 \\
\hline & $\begin{array}{l}\bar{\alpha} \\
\frac{u}{z} \\
\bar{z} \\
\bar{a} \\
\frac{\alpha}{\nu}\end{array}$ & 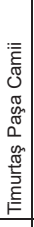 & 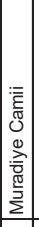 & $\begin{array}{l}: \overline{\bar{c}} \\
0 \\
0 \\
\frac{v}{0} \\
\frac{0}{0} \\
\sum \\
\frac{c}{\pi} \\
\infty \\
\infty\end{array}$ & 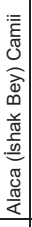 & 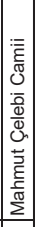 & 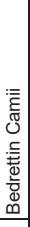 & 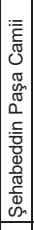 & 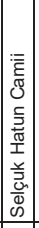 & 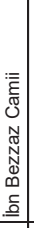 & 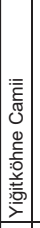 & 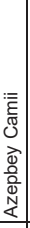 & 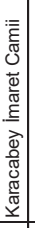 & 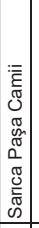 & 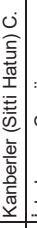 & 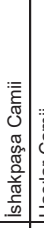 & 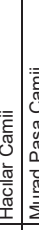 & 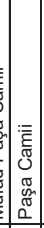 & 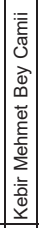 & 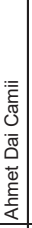 & 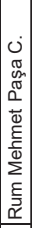 \\
\hline & 운 & - & N & $m$ & $\theta$ & in & 0 & $\sim$ & $\infty$ & 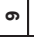 & 우 & $\mp$ & $\simeq$ & 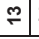 & \pm & 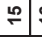 & $\div$ & $\stackrel{\infty}{=}$ & $\div$ & ล & $\bar{n}$ \\
\hline
\end{tabular}




\begin{tabular}{|c|c|c|c|c|c|c|c|c|c|c|c|c|c|c|c|c|c|c|c|c|c|}
\hline \multirow{3}{*}{ 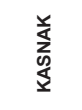 } & $\forall า อ ู ก \perp$ & - & & & & & & & & & & & & & & & & & & - & \\
\hline & $\S \forall \perp / \forall า อ ู ก \perp$ & & - & 0 & - & 인 & - & - & $\bullet$ & - & - & - & $\bullet$ & - & - & - & 0 & 0 & $\bullet$ & & 0 \\
\hline & $\delta \forall I$ & & & & & & & & & & & & & & & & & & & & \\
\hline \multirow{4}{*}{ 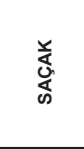 } & 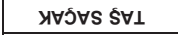 & $\bullet$ & & & & & & & & 0 & & - & & & & & & & & & \\
\hline & 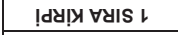 & & & & & & & & & & & & & & & & & & & & \\
\hline & 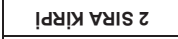 & & - & $\bullet$ & - & 0 & - & - & $\bullet$ & & - & & $\bullet$ & - & $\bullet$ & - & 0 & 0 & 0 & & 0 \\
\hline & 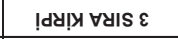 & $\bullet$ & & & & & & & & & & & & & & 0 & & & & $\bullet$ & \\
\hline \multirow{3}{*}{ 䍃 } & 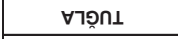 & $\bullet$ & - & - & & 0 & - & - & - & & & - & & - & - & - & 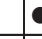 & 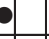 & & - & \\
\hline & 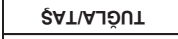 & & 은 & 0 & - & - & & & & 0 & - & & - & & & & 0 & 0 & - & - & - \\
\hline & $\delta \forall \perp$ & & & & & & & & & & & & & & & & & & & & \\
\hline \multirow{4}{*}{ 点 } & 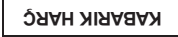 & & & & & 0 & & & & & & & & 0 & - & & & & - & & \\
\hline & эพАу & & & & & & & & & & & & & & & & & & & & \\
\hline & S!̣Nヨอ & - & 0 & & - & - & - & - & $\bullet$ & $\bullet$ & - & - & $\bullet$ & - & - & - & $\bullet$ & 0 & $\bullet$ & - & - \\
\hline & પ્રાર์ $\forall N \forall \lambda$ & & & - & & & & & & & & & & & & & & & & & \\
\hline \multirow{7}{*}{ 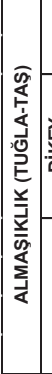 } & 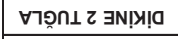 & 0 & - & 0 & & & & - & 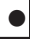 & 0 & & - & $\bullet$ & - & & & & & & $\bullet$ & \\
\hline & 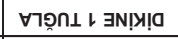 & & & & - & 0 & 0 & & & & - & & & & $\bullet$ & - & 0 & 0 & & - & \\
\hline & & & & & & & & & & & & & & & & & & & & & \\
\hline & $\frac{\gamma}{3}$ & & 0 & & - & & & & & & & & & & & & & & & & \\
\hline & ले & - & 0 & 0 & - & 0 & & - & & & - & & 0 & & & - & & 0 & 0 & 0 & 0 \\
\hline & $\bar{\lambda}$ & $\bullet$ & 0 & & & - & - & - & $\bullet$ & $\bullet$ & - & - & & 0 & $\bullet$ & & $\bullet$ & 0 & 0 & & \\
\hline & $\xi$ & & & & & & 0 & & & & & & & & & - & & - & & & \\
\hline \multirow{3}{*}{$\frac{\underset{\Sigma}{\mid}}{\stackrel{W}{\Sigma}}$} & 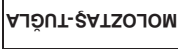 & & & & • & & 0 & & & & & & & ○ & - & - & $\bullet$ & $\bullet$ & - & & \\
\hline & 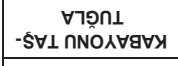 & 0 & 0 & & 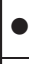 & - & & & $\bullet$ & & - & & - & 0 & - & - & 0 & 0 & & 0 & 0 \\
\hline & 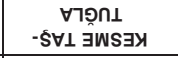 & & & $\bullet$ & & 0 & 0 & $\bullet$ & & $\bullet$ & & - & - & & & & & & & & 0 \\
\hline \multirow{4}{*}{ 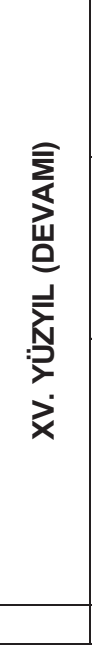 } & $\frac{\overrightarrow{\underline{T}}}{\frac{\bar{\alpha}}{\alpha}}$ & $\begin{array}{l}\frac{1}{4} \\
\end{array}$ & 竞 & 点 & 2 & $\mid$ & 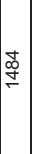 & 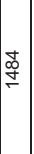 & 多 & $\underset{d}{d}$ & 梁 & 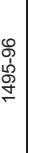 & 离 & לे & 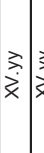 & 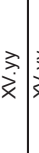 & $\overbrace{\vec{x}}^{>}$ & 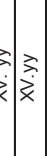 & $\mid \begin{array}{c}3 \\
\dot{x} \\
\times\end{array}$ & 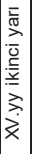 & $\begin{array}{l}0 \\
0 \\
\vdots \\
0 \\
0 \\
\grave{3} \\
\dot{x} \\
\dot{x}\end{array}$ \\
\hline & 妥 & 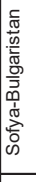 & 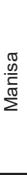 & 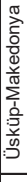 & 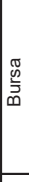 & 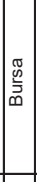 & 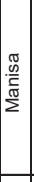 & 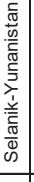 & 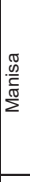 & 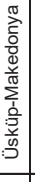 & 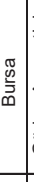 & 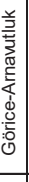 & $\frac{\pi}{\frac{\pi}{2}}$ & $\stackrel{\varrho}{\underline{\underline{E}}}$ & 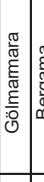 & 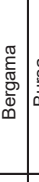 & & 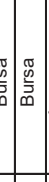 & 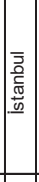 & & 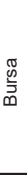 \\
\hline & $\begin{array}{l}\bar{\alpha} \\
z \\
\frac{z}{z} \\
\frac{a}{\alpha} \\
\searrow\end{array}$ & 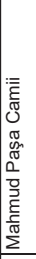 & 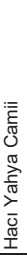 & 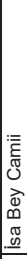 & 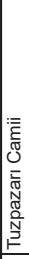 & 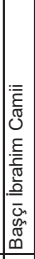 & 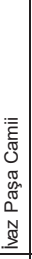 & 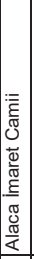 & 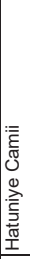 & 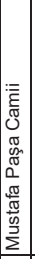 & 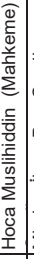 & 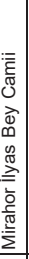 & 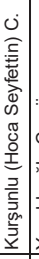 & 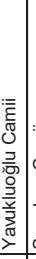 & 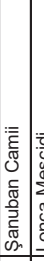 & 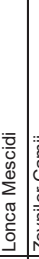 & 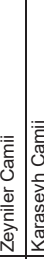 & 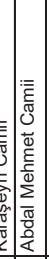 & 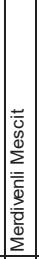 & 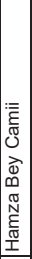 & 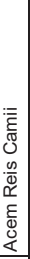 \\
\hline & 울 & ล & กิ & A & กี & i & $\hat{\mathbf{N}}$ & $\stackrel{\infty}{\infty}$ & ลิ & ले & $\bar{m}$ & ల్ల & $\ddot{m}$ & ले & 邑 & $\stackrel{m}{\infty}$ & $\hat{m} \mid \stackrel{m}{~}$ & : & \& & $\overline{7}$ & ร \\
\hline
\end{tabular}

